\title{
KONSEP DEEP ECOLOGY DALAM PENGATURAN HUKUM LINGKUNGAN
}

\author{
Edra Satmaidi \\ Fakultas Hukum Universitas Bengkulu \\ J1. WR. Supratman Kandang Limun Kota Bengkulu \\ Email: edra_fhunib@yahoo.com
}

\begin{abstract}
Damage and pollution of the environment is driven by the dominance of anthropocentric concepts in environmental and natural resources management that are backed-up by the sectoral and partial regulations more to prioritize aspects of economic development but ignoring the sustainability of the environment. The concept of Deep Ecology's Arne Naess fight for the sustainability of ecological communities. In the concept of Deep Ecology, protection and saving the environment by humans basically moved from the awareness that humans are part of nature and environmental sustainability intended for the entire ecological community.Law No. 32 of 2009 on the Protection and Management of the Environment (UUPPLH 2009) which establishes the obligation of the planning of the Protection and Environmental Management (RPPLH), the Strategic Environmental Assessment (SEA), Spatial Planning (RTRW) at the policy level and Environmental Impact Assessment (EIA) within the framework of the licensing system for environmental management at the project level or activity must be understood as an effort to protect and maintain environmental carrying capacity as the implementation of the concept of Deep Ecology in the regulation of Indonesian environmental law.
\end{abstract}

Keywords: Deep ecology concept, Environmental law, Regulation

\begin{abstract}
Abstrak
Kerusakan dan pencemaran lingkungan hidup didorong oleh masih dominannya konsep antroposentris dalam pengelolaan lingkungan hidup dan sumber daya alam yang diback-up oleh peraturan yang bersifat sektoral dan parsial yang lebih memprioritas aspek pembangunan ekonomi tetapi mengabaikan keberlanjutan fungsi lingkungan hidup.Konsep Deep Ecology dari Arne Naess memperjuangkan keberlanjutan komunitas ekologis. Dalam konsep Deep Ecology, perlindungan dan penyelamatan lingkungan hidup yang dilakukan manusia pada dasarnya beranjak dari kesadaran bahwa manusia merupakan bagian dari alam dan keberlanjutan lingkungan hidup diperuntukan bagi seluruh komunitas ekologis.Undang-Undang Nomor 32 Tahun 2009 tentang Perlindungan dan Pengelolaan Lingkungan Hidup (UUPPLH 2009) yang menetapkan kewajiban penyusunan Rencana Perlindungan dan Pengelolaan Lingkungan Hidup (RPPLH), Kajian Lingkungan Hidup Strategis (KLHS), Rencana Tata Ruang Wilayah (RTRW) di level kebijakan dan Analisis Mengenai Dampak Lingkungan Hidup (AMDAL) dalam kerangka sistem perizinan pengelolaan lingkungan hidup di level proyek atau kegiatan harus dipahami sebagai upaya untuk melindungi dan memelihara daya dukung dan daya tampung lingkungan hidup (DDDTLH) sebagai implementasi konsep Deep Ecology dalam pengaturan hukum lingkungan Indonesia.
\end{abstract}

Kata Kunci: Konsep deep ecology, Hukum lingkungan, Pengaturan

\section{PENDAHULUAN}

Dewasa ini telah mulai
disadari bahwa masalah
lingkungan hidup bukan hanya
masalah lingkungan fisik

manusia. Masalah lingkungan hidup bukan hanya masalah biologis manusia. Tetapi juga masalah moral. Kerusakan alam seperti erosi, banjir, longsor, kerusakan dan kebakaran hutan 
bukan hanya menimbulkan kecemasan bagi nasib hidup manusia, tetapi menimbulkan keprihatinan betapa perilaku manusia telah melampaui khittah-nya ${ }^{1}$ sebagai manusia yang seharusnya mengelola alam ini dengan bijak.

Masalah sumber daya alam dan lingkungan hidup telah berkembang menjadi krisis lingkungan global yang berdampak serius bagi keberlanjutan kehidupan manusia dan pembangunan. Sebagai reaksi terhadap krisis ini, sejak memasuki abad ke-20 telah tumbuh dan berkembang pergerakan lingkungan yang dilandasi dengan pendekatan ecosophy dimana filosofi penyelamatan bumi memasukkan dimensi ekologi dan dimensi spritual. Filsafat ecosophy atau deep ecology ini diperkenalkan pertama kalinya pada tahun 1972 oleh Arne Naess, filsuf dari Norwegia. ${ }^{2}$

Arne Naess menyatakan bahwa krisis lingkungan dewasa ini hanya dapat diatasi dengan melakukan perubahan cara pandang dan perilaku manusia terhadap alam secara

\footnotetext{
${ }^{1}$ Deni Bram, Hukum Lingkungan Hidup: dari Homo Ethic ke Homo Ethic, Gramata Publishing, Bekasi, 2014, hlm. 3

${ }^{2}$ Sinopsis Buku Hadi S. Alikodra, Konservasi Sumber Daya Alam dan Lingkungan Hidup: Pendekatan Ecosophy bagi Penyelamatan Bumi, Gadjah Mada University Press, Yogyakarta, 2012, www.wwf.or.id/?26300/WWF
}

fundamental dan radikal. ${ }^{3}$ Krisis lingkungan global dewasa ini sebenarnya bersumber pada kesalahan fundamental-filosofis dalam pemahaman atau cara pandang manusia mengenai dirinya, alam dan tempat manusia dalam keseluruhan ekosistem. Pada gilirannya, kekeliruan cara pandang ini melahirkan perilaku yang keliru terhadap alam. Manusia keliru memandang alam dan keliru menempatkan diri dalam konteks alam semesta seluruhnya. Inilah awal dari seluruh bencana lingkungan hidup yang kita alami sekarang. ${ }^{4}$ Dalam konteks pengelolaan lingkungan hidup, kekeliruan cara pandang manusia yang menganggap dirinya bukan merupakan bagian dari alam atau bagian dari keseluruhan ekosistem menyebabkan manusia tidak menyadari bahwa kerusakan ekologi akibat pengelolaan lingkungan hidup yang terlalu bertumpu pada kepentingan manusia (antroposentris) pada akhirnya berhadapan dengan diri manusia itu sendiri. ${ }^{5}$

\section{TINJAUAN PUSTAKA}

$\begin{array}{lr}\text { Ekosentrisme } & \text { adalahh } \\ \text { suatu teori etika lingkungan } \\ \text { yang memusatkan etika pada }\end{array}$

${ }^{3}$ Arne Naess dalam Sonny Keraf, Etika Lingkungan, PT. Kompas Media Nusantara, Jakarta, 2006, hlm. XIV

${ }^{4}$ Ibid., hlm. XIV-XV

5 Koesnadi Hardjasoemantri, Hukum Tata Lingkungan, Edisi VIII, Cetakan Kesembilan Belas, Gadjah Mada University Press, Yogyakarta, 2006, Hlm. 4 
seluruh komunitas ekologi, baik yang hidup maupun yang tidak hidup. Secara ekologis, makluk hidup dan benda-benda abiotis lainnya saling terkait satu sama lain. Oleh karena itu, kewajiban dan tanggung jawab moral tidak hanya dibatasi pada makluk hidup tetapi juga berlaku terhadap semua realitas ekologis. ${ }^{6}$

Salah satu versi teori ekosentrisme adalah "deep ecology". Deep ecology (DE) menuntut suatu etika baru yang tidak berpusat pada manusia, tetapi berpusat pada makhluk hidup seluruhnya dalam kaitan dengan upaya mengatasi persoalan lingkungan hidup. ${ }^{7} \mathrm{DE}$ mempersoalkan secara mendasar cara pandang dan pemahaman etika antroposentris dalam melihat hubungan manusia dengan alam.

Etika antroposentris mendapatkan banyak kritikan dan kecaman karena lebih menempatkan manusia sebagai manusia biologis yang memiliki cara pandang "hidup untuk hidup" bahkan lebih sempit lagi "hidup untuk manusia". ${ }^{8}$ Etika antroposentris menjauhkan manusia sebagai manusia ekologis dan manusia idealis yang memiliki kesadaran bahwa

6 Ibid., hlm. 75-76

A. Sonny Keraf, Etika Lingkungan, PT. Kompas Media Nusantara, Jakarta, 2006, hlm. 76 8 Sunardi, Perlindungan Lingkungan: Sebuah Perspektif dan Spritualitas Islam, Program Studi Magister Ilmu Lingkungan Universitas Padjadjaran, Bandung, 2008, hlm. 41 kelangsungan hidupnya sangat tergantung pada manusia lain dan lingkungan sekitarnya serta sanggup mengorbankan dirinya untuk mencapai tujuan ideologisnya (misalnya hidup selaras dengan alam) yang biasanya melampui batas-batas kepentingan-kepentingan dirinya. 9

Krisis lingkungan dianggap terjadi karena perilaku manusia yang dipengaruhi oleh cara pandang antroposentris. Pola perilaku yang eksploitatif, destruktif dan tidak peduli terhadap alam tersebut dianggap berakar pada cara pandang yang hanya mementingkan kepentingan manusia. Apa saja boleh dilakukan manusia terhadap alam, sejauh tidak merugikan kepentingan manusia, sejauh tidak mempunyai dampak yang merugikan kepentingan manusia (dalam arti kepentingan jangka pendek). ${ }^{10}$ Kewajiban dan tanggung jawab moral manusia terhadap lingkungan - kalaupun itu ada semata-mata demi memenuhi kepentingan sesama manusia. ${ }^{11}$

Ditinjau dari perspektif ajaran Islam, yang tertuang dalam Al-Qur'an Surah AlBaqarah ayat 30 paradigma antroposentris bertentangan dengan tugas manusia sebagai khalifah fil ardhi dimana Allah SWT mengamanahkan tugas kepada manusia sebagai khalifah untuk mengelola atau

${ }^{9}$ Ibid., hlm. 41-43

10 Ibid., hlm. 35

11 Sonny Keraf, Op.cit., hlm. 
mengatur bumi. Konsep khalifah bermakna responsibility yakni hanya akan bermakna jika manusia mampu mengelola dan melindungi bumi sehingga seluruh peribadatan dan amalamal sosialnya dapat dengan tenang ditunaikan. ${ }^{12}$

$$
\text { Fritjof Capra dalam }
$$
artikelnya yang berjudul Deep Ecology: A New Paradigm menyatakan bahwa antroposentris adalah ekologi dangkal (shallow ecology) yang mempunyai cara pandang berbeda dengan ekologi dalam (deep ecology), dengan uraian sebagai berikut: 13

"Ekologi dangkal (shallow ecology) adalah antroposentris yang melihat manusia berada di atas atau di luar alam, sebagai sumber dari semua nilai, dan menganggap alam hanya sebagai suatu instrumen, atau menggunakan nilai kepada alam. Ekologi dalam (deep ecology) tidak memisahkan manusia dari lingkungan alam, maupun

12 Mudhofir Abdullah, AlQuran \& Konservasi Lingkungan (Argumen Konservasi Lingkungan Sebagai Tujuan Tertinggi Syariah, Dian Rakyat, Jakarta, 2010, hlm. 13-14 dan Fachruddin M. Mangunjaya dkk, Menanam Sebelum Kiamat, Islam, Ekologi, dan Gerakan Lingkungan Hidup, Yayasan Obor Indonesia, Jakarta, 2007, hlm. 5

${ }^{13}$ Fritjop Capra dalam George Sessions (Ed), Deep Ecology for Twenty-First Century, SHAMBHALA Boston \& London, 1995, hlm. 20. Lihat juga dalam Fritjop Capra, The Web of Life: A New Scientific Understanding of Living Systems, Doubleday, New York, 1996, hlm. 7 tidak memisahkan segala sesuatunya dari lingkungan alam. Deep Ecology tidak melihat dunia sebagai suatu kumpulan objek-objek yang terisolasi tetapi sebagai suatu jaringan fenomena yang saling terhubung dan saling ketergantungan secara fundamental. Deep ecology mengakui nilai-nilai instrinsik dari semua makluk hidup dan memandang manusia hanya sebagai salah satu bagian khusus dalam jaringan kehidupan (the web of life). Paradigma ekologi baru ini (deep ecology) menyiratkan sebagai suatu etika berorientasi ekologi yang sesuai. Kerangka etika yang terkait dengan paradigma lama tidak lagi memadai untuk menangani beberapa masalah etika utama saat ini, yang sebagian besar menyebabkan ancaman terhadap bentuk-bentuk kehidupan selain manusia."

Deep ecology yang oleh Capra disebut sebagai paradigma ekologi baru merupakan gagasan Arne Naess seorang filsuf Norwegia pada tahun 1973. Menurut Naess dalam mengatasi kondisi darurat ekologis (The Emergency of Ecologists) dapat dibedakan dua gerakan penyelamatan lingkungan yaitu shallow ecological movement (SEM) dan deep ecological movement (DEM).14 DEM perlu dipahami dalam latar belakang kritiknya terhadap antroposentrisme atau lebih luas
${ }^{14}$ George Sessions (Ed), Op.cit., hlm. 
dikenal sebagai shallow ecological movement (SEM) yang dapat dikemukakan sebagai berikut: 15

"SEM berasumsi bahwa krisis lingkungan merupakan persoalan teknis, yang tidak membutuhkan perubahan dalam kesadaran manusia dan sistem ekonomi. DEM justru sebaliknya, melihat permasalahan lingkungan dalam suatu perspektif relasional yang lebih luas dan holistik. DEM lebih berusaha untuk melihat akar permasalahan kerusakan dan pencemaran lingkungan secara lebih komprehensif dan holistik, untuk kemudian mengatasinya secara lebih mendalam. Aspek sosial dan manusia juga menjadi perhatian utama DEM. Sementara, SEM lebih cenderung mengatasi simptom atau gejala dari sebuah isu lingkungan dan bukan akar permasalahan (yang terutama dilihat adalah dampak langsung dari lingkungan, dan bukan sebab utama dampak itu).

Filsafat pokok DE disebut Naess sebagai ecosophy yang berarti kearifan mengatur hidup selaras dengan alam sebagai sebuah rumah tangga dalam arti luas. Dalam arti ini, lingkungan hidup tidak sekadar sebuah ilmu (science) melainkan sebuah kearifan (wisdom), sebuah cara hidup, sebuah pola hidup selaras dengan alam. Ini

\footnotetext{
${ }^{15}$ Sonny Keraf, Op.cit., hlm.90-92
}

menyangkut sebuah gerakan, gerakan dari semua penghuni rumah tangga, penghuni alam semesta untuk menjaga secara arif lingkungannya sebagai rumah tangga. 16

Dalam filsafat ecosophy terdapat suatu pendekatan yang mengintegrasikan dimensi intelektual, spritual dan emosional. Dimensi intelektual berarti umat manusia diminta secara terus menerus mempelajari, meneliti, memahami dan menghargai alam lingkungannya. Dimensi spritual berarti mempercayai bahwa SDA diciptakan oleh Tuhan Yang Maha Esa, perlu dilindungi dan dijaga kelestariannya karena berfungsi untuk mendukung kehidupan manusia. Sementara, dimensi emusional bermakna dalam membentuk manusia beretika dan bermoral bagi terjaminnya kualitas hidup manusia dari generasi ke generasi. ${ }^{17}$

Filsafat ecosophy ini menurut Naess harus dapat berfungsi sebagai landasan filosofis dalam rangka penerimaan prinsip-prinsip Deep Ecology, di antaranya: (a) sikap hormat terhadap semua cara dan bentuk kehidupan di alam semesta (biospheric egalitarianism-in principle); (b)

\footnotetext{
${ }^{16}$ Ibid., hlm. 78

17 Sinopsis Buku Hadi S.
} Alikodra, Konservasi Sumber Daya Alam dan Lingkungan Hidup: Pendekatan Ecosophy bagi Penyelamatan Bumi, Gadjah Mada University Press, Yogyakarta, 2012, www.wwf.or.id/?26300/WWF 
manusia hanya salah satu spesies di tengah begitu banyak spesies lain. Semua spesies ini mempunyai nilai yang sama (prinsip non-antroposentrisme); (c) prinsip realisasi diri yang memandang manusia tidak hanya sebatas sebagai makhluk sosial (social animal), tetapi juga makhluk ekologis (ecological animal); dan (d) Pengakuan dan penghargaan terhadap keanekaragaman dan kompleksitas ekologis dalam suatu hubungan simbiosis. ${ }^{18}$

\section{PEMBAHASAN}

Konsep Deep Ecology yang dilandasi filsafat ecosophy yang menghendaki adanya perubahan kebijakan dalam mengatasi krisis atau darurat lingkungan akibat eksploitasi sumber daya lingkungan yang mengabaikan aspek kelestarian dan daya dukung lingkungan (didasarkan pada etika antroposentris), memerlukan adanya hukum lingkungan sebagai wadah kebijakan pengelolaan lingkungan yang memuat kaidah-kaidah hukum yang sesuai dengan prinsip-prinsip DE sebagai etika ekosentrisme. Hukum lingkungan yang dimaksud memuat paradigma hukum yang berpihak kepada keberlanjutan lingkungan atau ekologi.

18 Arne Naess, Ecology, Community and Lifestyle, Cambridge University Press, United Kingdom, 1989, hlm. 38 dan Sonny Keraf, Op.cit., hlm. 91-96

\begin{abstract}
Hukum yang berpihak kepada keberlanjutan lingkungan atau ekologi menurut Munadjat Danusaputro merupakan hukum lingkungan moderen, yaitu: 19

"Hukum yang berorientasi kepada lingkungan (environmental-oriented law), dengan tujuan melindungi lingkungan dari kerusakan dan kemerosotan mutunya. Hukum lingkungan moderen merupakan antitesa hukum lingkungan klasik yang lebih berorientasi kepada penggunaan lingkungan (useoriented law), dalam arti menjamin penggunaan dan eksploitasi sumber-sumber daya lingkungan."
\end{abstract}

Menurut Munadjat dalam perspektif hukum lingkungan moderen, hukum lingkungan berguru kepada ekologi, yang banyak mengungkapkan dan menampilkan sifat-sifat dan hakikat lingkungan sebagai ekosistem. ${ }^{20}$ Dari pemahaman makna ekosistem dan lingkungan hidup, maka hukum lingkungan memiliki sifat utuh menyeluruh atau komprehensif integral. ${ }^{21}$

Hyronimus

Rhiti berpendapat bahwa hukum lingkungan berorientasi pada penataan atau pengaturan perilaku manusia. Perilaku manusia yang harus diatur terlebih dahulu, bukan perilaku

19 St. Munadjat Danusaputro, Hukum Lingkungan, Buku I, Binacipta, Bandung, 1981, hlm. 3536

20 Ibid.,hlm. 36

${ }^{21}$ Ibid. 
alam atau lingkungan hidup. Alam atau lingkungan hidup mempunyai hukum-hukumnya sendiri yang bersifat deterministik. Perilaku manusia harus diatur, sebab dari perilaku manusia-lah segala beban (umweltbelastung) atau masalah bagi lingkungan hidup itu muncul. Kalau perilaku manusia terhadap lingkungan hidupnya baik, maka akan baik pula lingkungan hidupnya. ${ }^{22}$ Dengan kata lain, perilaku manusia dalam interaksinya dengan alam dan lingkungan harus diatur dalam hukum lingkungan sehingga perilaku manusia tersebut selaras dengan alam dan lingkungan. Agar perilaku manusia yang diatur dalam hukum lingkungan itu selaras dengan alam dan lingkungan maka sumber hukum lingkungan itu terutama berasal dari hukum alam (the rule of nature), seperti: hukum termodinamika terhadap pencemaran dari penggunaan energi, hukum gravitasi terhadap terjadinya longsor, banjir, dan sebagainya) dan ilmu yang menjadi alat ukur dampaknya, seperti: penerapan AMDAL sebagai analisis ongkos dan manfaat suatu rencana kegiatan, ${ }^{23}$ dan pelaksanaan KLHS dalam penyusunan atau evaluasi kebijakan, rencana dan program pembangunan. Sehingga kebijakan, rencana dan program pembangunan

22 Hyronimus Rhiti, Hukum Penyelesaian Sengketa Lingkungan, Universitas Atma Jaya, Yogyakarta, 2006, hlm. 1-2

23 Daud Silalahi, Pelatihan Hukum Pidana Khusus Bagi Hakim Tinggi - Medan, hlm. 191 mempertimbangkan dan mengintegrasikan prinsip-prinsip pembangunan berkelanjutan.

Anne Daniel menyatakan bahwa pendekatan perundangundangan di masa yang akan datang perlu memberikan perhatian kepada pelaksanaan substantif dari pembangunan berkelanjutan melalui konsep daya dukung ekosistem dan metode-metode lain yang memadukan kepedulian lingkungan dengan kebutuhan sosial-ekonomi. Hukum dapat menyediakan instrumen yang akan berguna sebagai pedoman bagi perilaku manusia, dan di mana perlu, memaksakannya. Dengan jalan ini, hukum dapat memberikan landasan bagi perubahan perilaku yang diperlukan bagi pengembangan masyarakat yang benar-benar berkelanjutan. ${ }^{24}$

World Commission on Environment and Development (WCED) tahun 1991 menerbitkan suatu laporan yang berjudul Caring for the Earth: A Strategy for Sustainable Living yang menegaskan arti penting hukum lingkungan sebagai sarana untuk mengupayakan keberlanjutan lingkungan dalam rangka mewujudkan pembangunan berkelanjutan, yang menyatakan sebagai berikut : 25

"Untuk menetapkan dan melaksanakan

pembangunan hlm. 35-36

${ }^{24}$ Koesnadi Hardjasoemantri, Op.cit.,

${ }^{25}$ R.M. Gatot P. Soemartono, Hukum Lingkungan Indonesia, Sinar Grafika, Jakarta, 2004, hlm. 36-37 


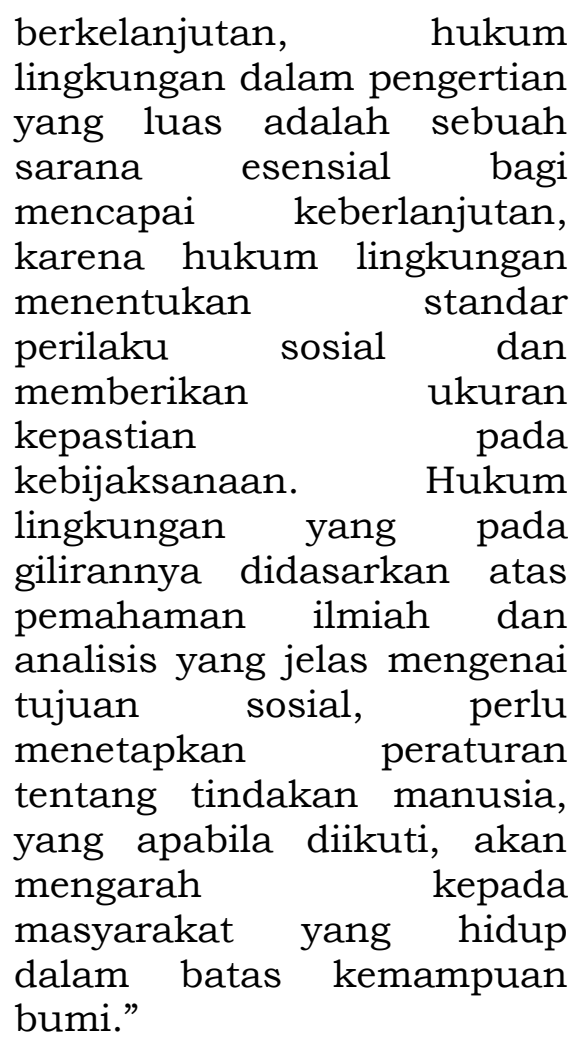

\section{Pembangunan}

berkelanjutan tentunya tidak sulit dapat diwujudkan apabila karakter hukum lingkungan masih bersifat insidental, komensalis (menempatkan hukum lingkungan sebagai minority regulation), parsial dan sektoral (mengedepankan hukum sektoral yang seringkali tidak sinkron dengan peraturan hukum terkait), serta bersifat jalan pintas (seharusnya diatur dengan peraturan yang lebih tinggi tetapi diatur dengan peraturan yang lebih rendah (misalnya dengan Peraturan Menteri). ${ }^{26}$ Oleh karena itu, sifat dan wawasan peraturan perundang-undangan

lingkungan yang akan ditata

26 N.H.T. Siahaan, Hukum Lingkungan dan Ekologi Pembangunan, Edisi Kedua, Erlangga, Jakarta, 2004, hlm. 381-385 harus memperlihatkan 3 (tiga) karakter atau corak kebijaksanaan hukum, yaitu:27

1. Regulasi bersifat environmental policy yaitu regulasi yang ditujukan khusus untuk menata satuan-satuan lingkungan/ekosistem.

2. Regulasi bersifat integral policy. Dalam corak regulasi ini, sektor non-lingkungan hidup menjadi porsi utama dari tujuan pembuatan peraturan perundangundangan tetapi tetap diperhatikan dan dirumuskan beberapa pasal konservasi dan perlindungan lingkungan. Setiap peraturan perundang-undangan yang dibuat saling menunjang dan sejalan, tidak akan bertentangan dengan kebijaksanaan-

kebijaksanaan lingkungan yang telah ditempuh. Setiap peraturan perundangan harus mencerminkan integralisasi atas berbagai pola kebijaksanaan lingkungan yang ditetapkan.

3. Regulasi bersifat supporting policy/beyond policy, dalam arti regulasi hukum di semua sektor, sepanjang masih mampu dilibatkan untuk mendorong ditingkatkannya partisipasi pembinaan lingkungan.

$\begin{array}{lr}\text { Peraturan } & \text { perundang- } \\ \text { undangan dalam } & \text { perspektif } \\ \text { hukum lingkungan } & \text { moderen } \\ \text { menempatkan } & \text { asas } \\ \text { keberlanjutan sebagai suatu } \\ \text { asas penting yang mendasari }\end{array}$

${ }^{27}$ Ibid., hlm. 389-392 
kaidah-kaidah pengaturan dalam perundang-undangan tersebut. Hal ini disebabkan sustainabilitas (keberlanjutan) telah menjadi isu penting dalam pembangunan ekonomi dunia, karena masyarakat dunia sudah menyadari bahwa eksploitasi sumber daya alam dapat mengakibatkan kelangkaan sumberdaya, degradasi lingkungan, dan penurunan kualitas lingkungan. Oleh karenanya, pembangunan ekonomi harus mengarah ke pembangunan yang berwawasan lingkungan atau pembangunan berkelanjutan. ${ }^{28}$ Pembangunan berkelanjutan menempatkan lingkungan hidup dan sumber daya alam tidak saja sebagai modal pertumbuhan ekonomi (resource based economy), tetapi juga sebagai penopang sistem kehidupan (life supporting system), sehingga fungsi dan daya dukung lingkungan hidup perlu dilestarikan. ${ }^{29}$

\begin{tabular}{lrr}
\multicolumn{2}{c}{ Pelestarian } & fungsi \\
lingkungan & hidup & dan \\
pembangunan & berkelanjutan
\end{tabular}
merupakan tujuan utama yang hendak dicapai dengan ditetapkannya Undang-Undang Nomor 32 Tahun 2009 tentang perlindungan dan pengelolaan lingkungan hidup (UUPPLH). Tercapainya pelestarian fungsi lingkungan hidup dan pembangunan berkelanjutan diukur dari terjaganya daya dukung dan daya tampung lingkungan hidup (DDDTLH).

\footnotetext{
${ }^{28}$ Ibid., hlm. 18

29 Ida Nurlinda, Prinsip-Prinsip Pembaruan Agraria Perspektif Hukum. Rajawali Pers, Jakarta, 2009 , hlm. 191.
}

Bila dipahami UUPPLH, penyusunan Rencana Perlindungan dan Pengendalian Lingkungan Hidup (RPPLH), penyusunan Kajian Lingkungan Hidup Strategis (KLHS), dan penyusunan Analisis Mengenai Dampak Lingkungan Hidup (AMDAL) dalam kerangka sistem perizinan lingkungan bagi usaha dan/atau kegiatan yang berdampak penting bagi lingkungan hidup bertujuan untuk memastikan agar DDDTLH tetap terjaga sehingga dapat mendukung pembangunan berkelanjutan. RPPLH dan KLHS berada pada tataran hulu atau berada pada level Kebijakan, Rencana dan Program (KRP), sementara AMDAL berada pada tataran hilir yaitu pada level kegiatan atau proyek.

Menurut

UUPPLH, pemanfaatan sumber daya alam dan penyusunan rencana pembangunan jangka panjang (RPJP) dan rencana pembangunan jangka menengah (RPJM) harus berdasarkan RPPLH karena melalui RPPLH telah ditentukan rencana mengenai pemanfaatan, pencadangan, pengendalian, dan pelestarian sumber daya alam; pemeliharaan dan perlindungan fungsi lingkungan hidup, dan adaptasi dan mitigasi terhadap perubahan iklim. Dalam hal RPPLH belum tersusun, pemanfaatan sumber daya alam dilaksanakan berdasarkan DDDTLH.

Begitu pula, kewajiban Pemerintah dan Pemerintah Daerah menyusun dan 
melaksanakan KLHS adalah untuk memastikan DDDTLH tidak terlampaui. Dibuktikan dari kewajiban membuat dan melaksanakan KLHS hanya dalam penyusunan atau evaluasi Rencana Tata Ruang Wilayah (RTRW), RPJP/RPJM dan KRP yang berpotensi menimbulkan dampak/risiko lingkungan hidup. Kewajiban KLHS tersebut untuk memastikan bahwa prinsip pembangunan berkelanjutan dengan mengedepankan DDDTLH telah menjadi dasar dan terintegrasi dalam pembangunan suatu wilayah dan/atau KRP pembangunan. Oleh karena itu, menurut UUPPLH pemerintah atau pemerintah daerah dalam melakukan penyusunan KLHS harus memuat kajian: (a). kapasitas daya dukung dan daya tampung lingkungan hidup untuk pembangunan; (b). perkiraan mengenai dampak dan risiko lingkungan hidup; (c). kinerja layanan/jasa ekosistem; (d). efisiensi pemanfaatan sumber daya alam; (e). tingkat kerentanan dan kapasitas adaptasi terhadap perubahan iklim; dan (f). tingkat ketahanan dan potensi keanekaragaman hayati. Dengan demikian, hasil KLHS harus dijadikan dasar bagi KRP pembangunan dalam suatu wilayah. Apabila hasil KLHS menyatakan bahwa DDDTLH sudah terlampaui, KRP pembangunan tersebut wajib diperbaiki sesuai dengan rekomendasi KLHS dan segala usaha dan/atau kegiatan yang telah melampaui DDDTLH tidak diperbolehkan lagi.
Semangat mengedepankan DDDTLH pun terlihat dalam kerangka sistem perizinan pengelolaan lingkungan hidup dan pemanfaatan sumber daya alam dimana UUPPLH menempatkan AMDAL sebagai instrumen wajib (mandatory instrument), prasyarat untuk memperoleh izin lingkungan dan izin lingkungan sebagai prasyarat untuk mendapatkan izin usaha atau kegiatan. Fungi AMDAL ditempatkan secara vital untuk menganalisa secara komprehensif seluruh komponen lingkungan dan kegiatan serta dampaknya dalam rangka internalisasi pertimbangan lingkungan dalam proses perencanaan, pembuatan program dan pengambilan keputusan.

$\begin{array}{llr}\text { AMDAL } & \text { sebagai scientific } \\ \text { prediction } & \text { yang memberikan } \\ \text { gambaran } & \text { yang jelas secara } \\ \text { alamiah tentang analisis } & \\ \text { kegiatan dan dampak yang }\end{array}$
mungkin akan ditimbulkan oleh sebuah kegiatan. Begitu pula AMDAL merupakan scientific evidence yang memberikan deskripsi tentang kegiatan dan/usaha yang layak dan tidak layak secara ekologis. UUPPLH menempatkan Amdal sebagai bagian dari sistem perizinan dimana AMDAL sebagai teknis analisa lingkungan dengan izin sebagai legalitasnya. Dalam rangka menjamin AMDAL suatu rencana usaha/ kegiatan sesuai dengan DDDTLH, Peraturan Pemerintah Nomor 27 Tahun 2012 Tentang Izin Lingkungan mewajibkan lokasi rencana Usaha dan/atau kegiatan sesuai 
dengan rencana tata ruang (RTRW), yang mengacu pada Undang-Undang Nomor 26 Tahun 2007 tentang Penataan Ruang. Dalam hal lokasi rencana usaha dan/atau kegiatan tidak sesuai dengan RTRW, dokumen Amdal tidak dapat dinilai.

\section{Persyaratan penyusunan} AMDAL suatu rencana usaha/ kegiatan sesuai dengan RTRW adalah sudah tepat karena RTRW menentukan alokasi peruntukan ruang untuk berbagai kegiatan pembangunan berdasarkan pertimbangan DDDTLH dengan pendekatan sistem kawasan yang dibedakan dalam kawasan lindung dan kawasan budidaya. Kawasan lindung menekankan pada daya dukung lingkungan bagi sistem penyangga kehidupan yang harus dipertahankan, sementara kawasan budidaya mengakamodir berbagai kegiatan pembangunan yang dapat ditampung sesuai dengan kemampuan lingkungan. Dengan kata lain, walaupun dokumen AMDAL sudah mengambarkan kelayakan lingkungan suatu rencana usaha/ kegiatan, namun jika lokasinya tidak sesuai dengan RTRW yang menekankan pertimbangan
DDDTLH dalam menentukan kegiatan mana yang dapat dilakukan pada kawasan lindung atau pada kawasan budidaya, maka rencana usaha/kegiatan yang telah dilengkapi dokumen AMDAL tersebut tidak dapat diproses perizinannya.

\section{KESIMPULAN}

Konsep deep ecology yang menjadikan teori ekosentrisme sebagai basis nilai-nilai dan moral gerakannya telah membawa perubahan yang radikal terhadap cara pandang manusia terhadap alam dan memperlakukan alam sebagai sesuatu yang mempunyai nilai instrinsik yang perlu dihormati dan dijaga oleh manusia sebagai bagian dari alam dalam rangka terselenggaranya kehidupan dalam suatu tatanan ekologis. Keberadaan hukum lingkungan menjadi instrumen untuk memelihara keberlanjutan ekologis tersebut dengan kaidahkaidah pengaturannya yang berorientasi pada lingkungan sebagai suatu kesatuan ekosistem. 


\section{DAFTAR PUSTAKA}

Arne Naess, 1989., Ecology, Community and Lifestyle, United Kingdom.,Cambridge University Press.

Deni Bram, 2014., Hukum Lingkungan Hidup: dari Homo Ethic ke Homo Ethic, Bekasi: Gramata Publishing.

Fachruddin M. Mangunjaya dkk, 2007. Menanam Sebelum Kiamat, Islam, Ekologi, dan Gerakan Lingkungan Hidup, Jakarta: Yayasan Obor Indonesia,

Fritjop Capra, 1996. The Web of Life: A New Scientific Understanding of Living Systems, Doubleday, New York.

George Sessions (Ed), 1995. Deep Ecology for TwentyFirst Century, Boston \& London : SHAMBHALA.

Hyronimus Rhiti, 2006: Hukum Penyelesaian Sengketa Lingkungan, Yogyakarta: Universitas atma Jaya.

Ida Nurlinda, 2009. PrinsipPrinsip Pembaruan Agraria Perspektif Hukum. Jakarta: Rajawali Pers.

Koesnadi Hardjasoemantri, 2006. Hukum Tata Lingkungan, Yogyakarta: Gadjah Mada University Press, Edisi VIII, Cetakan Kesembilan Belas.

Mudhofir Abdullah, 2010. AlQuran \& Konservasi
Lingkungan (Argumen

Konservasi Lingkungan

Sebagai Tujuan Tertinggi

Syariah, Jakarta: Dian

Rakyat.

N.H.T. Siahaan, , 2004, Hukum Lingkungan dan Ekologi Pembangunan, Jakarta: Erlangga, Edisi Kedua.

R.M. Gatot P. Soemartono, . 2004. Indonesia, Jakarta: Sinar Grafika.

Sonny Keraf, 2006 Etika Lingkungan, Jakarta: PT. Kompas Media Nusantara,

St. Munadjat Danusaputro, 1981. Hukum Lingkungan, Bandung: Binacipta, Buku I.

Sunardi, 2008. Perlindungan Lingkungan: Sebuah Perspektif dan Spritualitas Islam, Bandung: Program Studi Magister Ilmu Lingkungan - Universitas Padjadjaran.

\section{Internet}

Daud Silalahi, Tindak Pidana Lingkungan Dalam Sistem Hukum Lingkungan Indonesia,http://www.pkh.k omisiyudisial.go.id/id/files/ Materi/TINGGI01/TINGGI01 _DAUD_TPL.pdf.

Hadi S. Alikodra, Sinopsis Buku Konservasi Sumber Daya Alam dan Lingkungan Hidup: Pendekatan Ecosophy bagi Penyelamatan Bumi, Gadjah 
Jurnal Penelitian Hukum

Supremasi Hukum,

\author{
Mada University Press, \\ Yogyakarta, 2012, \\ www.wwf.or.id/?26300/WW \\ $\underline{F}$
}

